disorders has yielded potential diagnostic and therapeutic applications. ${ }^{3}$

In the late nineteenth century, $\mathrm{Dr}$ Willoughby reported in The Lancet that pilocarpine was a effective treatment for threatening mania. ${ }^{4}$ The case was a man of "powerful build and abstemious habits" who presented with sleeplessness, poor appetite, and "singing, shouting, gesticulating, snapping his fingers, talking wildly and seeing illusions". After the patient had failed to respond to chloral hydrate and opium, Willoughby injected him with one-sixth of a grain $(10.8 \mathrm{mg})$ of pilocarpine. After profuse salivation and sweating, the patient became "perfectly calm and rational, his skin was cool and moist, temperature in the mouth $99^{\circ}$, his head clear, and appetite returning". Although this treatment for mania went largely unnoticed and has been overlooked by medical historians, the case is an early illustration of the now wellestablished antimanic properties of centrally acting cholinomimetic agents.

Department of Psychiatry,

Yale University School of Medicne,

New Haven, CT 06509, USA

MARK OLFSON

1 Janowsky DS, El-Yousef MK, Davis JM, Hubbard B, Sekerke HJ. Cholmergic reversal of manic symptoms. Lancet 1972, i: 1236-37.

2. Janowsky DS, El-Yousef MK, Davis JM, Sekerke HJ. A Cholinergic-adrenergic hypothess of mania and depression. Lancet 1972; ii: 632-35.

3 Janowsky DS, Risch SC, Gillin C. Adrenergic-cholinergic balance and the treatmen of affective disorders. Prog Neuro-Psychopharmacol Biol Psychiair 1983; 7: 297.

4. Willoughby EF. Plocarpine in threatening mania. Lancet 1889; i: 1030.

\section{LACK OF EFFICACY OF PLASMA-EXCHANGE IN REMOVING ANTIPHOSPHOLIPID ANTIBODIES}

SIR,-The presence of antiphospholipid antibodies (antiPL Ab), especially lupus anticoagulant (LAC) and anticardiolipin antibodies (ACA), characterises a subset of lupus patients with a high prevalence of fetal wastage. ${ }^{1,2}$ It has been suggested that a steroid-induced reduction of antibody levels during pregnancy improves fetal outcome, ${ }^{3}$ but side-effects inevitably occur with high doses of prednisone. ${ }^{4}$ Plasma-exchange has been used successfully in antibody-mediated disorders, and can be done safely for long periods during pregnancy. ${ }^{5}$

We have investigated whether plasma exchange might be an acceptable alternative to prednisone in reducing circulating antiPL $\mathrm{Ab}$. In four non-pregnant SLE patients, who gave informed consent and were not treated with immunosuppressive drugs, we assayed LAC and ACA levels for 14 days after a single plasma exchange.

LAC was measured with the kaolin clotting time $(\mathrm{KCT}) ;^{6}$ an index of more than 17 indicates the presence of LAC. ACA was measured by an enzyme-linked immunosorbent assay. ${ }^{7}$ Three patients had LAC and four had raised ACA levels before plasma exchange (figure). In samples taken $2 \mathrm{~h}$ after the removal of one plasma volume (range: $2250-2650 \mathrm{ml}$ ) antiPL Ab levels were decreased compared with pre-exchange values. One of the three LAC-positive patients had a negative LAC assay; ACA levels
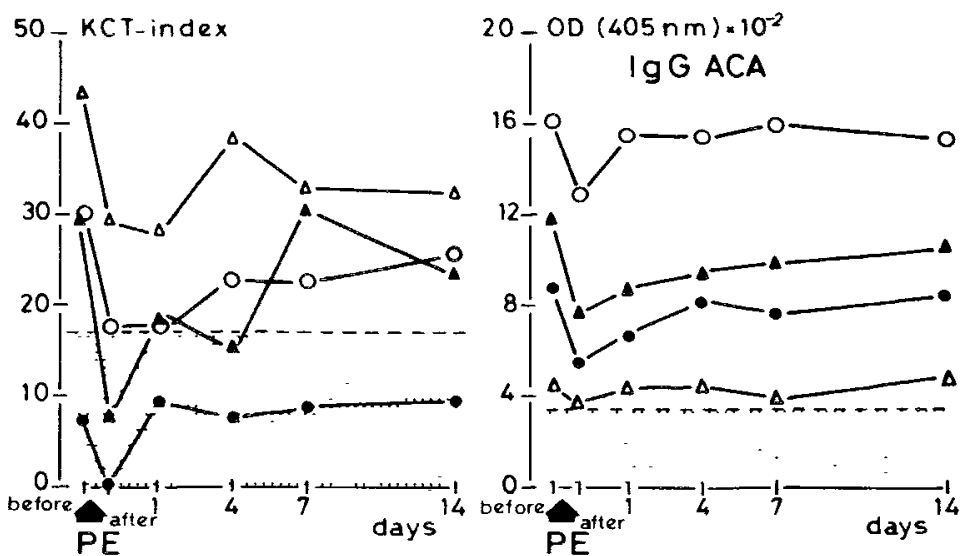

Effect of exchange of one circulating plasma volume on LAC (KCT-index) and IgG ACA in four patients.

Interrupted horizontal line =upper limit of normal (mean +SD); $\mathrm{OD}=$ optical density; and $\mathrm{PE}=$ plasma exchange decreased but remained above the normal range. $24 \mathrm{~h}$ after plasma exchange $\mathrm{LAC}$ was again detectable in the three previously positive patients. During the 14 days after the exchange the KCT index increased gradually, but remained below the pre-exchange level. In contrast, ACA levels returned to pre-exchange values within 7 days.

To obtain and maintain a negative LAC assay our data indicate that plasma exchange would have to be done several times per week, which would make plasma exchange a cumbersome and costly alternative to prednisone. Compared with LAC a sustained reduction of ACA levels seems to be even more difficult by plasma exchange. It remains to be established whether a combination of plasma exchange with a low dose of prednisone would be an effective approach

This study was supported by grant no 85 CR 46 from the Nederlandse Vereniging voor Reumabestrijding.

$\begin{array}{ll}\text { Departments of Internal Medicine } & \text { R. H. W. M. DERKSEN } \\ \text { (Division of Immunopathology) } & \text { P. HASSELAAR } \\ \text { and Haematology, } & \text { L. BLOKZIJL } \\ \text { University Hospital, } & \text { P. G. DE GROOT } \\ \text { 3511 Utrecht, The Netherlands } & \end{array}$

1. Derksen RHWM, Bouma BN, Kater L. The striking association between lupus anticoagulant and fetal loss in systemic lupus erythematosus. Arthritis Rheum 1986; 29: 695-96.

2. Derue G, Englert HJ, Harris EN, et al. Fetal loss in systemic lupus: Association with anticardiolıpin antibodies. 7 Obstet Gynaecol 1985; 5: 207-09.

3. Lubbe WF, Liggins GC. Lupus anticoagulant and pregnancy. Am $\mathcal{F}$ Obstet Gymecol 1985; 153: 322-27.

4. Feinstein DI. Lupus anticoagulant, thrombosis and fetal loss. N Engl f Med 1985; 313: 1348-50.

5. Fraser ID, Bothamley JE, Bennett $M O$, et al. Intensive antenatal plasmapheresis in severe rhesus isoimmunisation. Lancet 1976; 1: 6-8.

6. Rosner E, Pauzner R, Lusky A, et al. Detection and quantitative evaluation of lupus circulating anticoagulant activity. Thromb Hoemost 1987; 57: 144-47.

7. Derksen RHWM, Biesma D, Bouma BN, et al. Discordant effects of prednisone on anticardiolipin antibodies and the lupus anticoagulant. Arthrtis Rheum 1986; 29: 1295-96.

\section{MUSCLE CONTRACTION AND TENSION HEADACHES}

SIR,-Dr Indo (June 13, p 1370) highlights a current confusion between tension headache and muscle contraction headache. A mechanism postulated for tension headache some 20 years agothat muscle contraction is the cause of the pain-has not withstood the test of time. Hence a dilemma.

Fact and fiction, observation and hypothesis must always be distinguished. The fact is that clinically one can recognise two types of headache.

Type I is a sensation of a continuous band round the head or pressure "like a weight on top of my head" present on waking and lasting throughout the day, most days or every day of the week, uninfluenced by analgesics, worsened by emotion, and without physical signs.

Type II is a localised pain (usually over the temporalis or occipital muscles), often unilateral, lasting a few hours (on waking and disappearing by noon, or starting in the evening and lasting until bedtime), tender to touch, influenced by the application of heat or cold, relieved by massage with fingertips, and eased or abolished in 20-30 minutes by analgesics for 3-4 hours. Examination shows localised tender areas, and movement of the affected muscle often increases the pain.

The first headache is called a tension headache - a bad term because it does not distinguish between a tense patient and tense muscles. The second is a muscle headache similar to the muscle pains that occur after undue or unaccustomed exercise.

There are, of course, patients with both types of headache, and the two types may be difficult to distinguish in a given patient, but with close attention they can be separated.

To help us think clearly we may need new terms. The localised muscle pain could be called "localised head muscle pain", and here we need to specify which muscle is involved to localise the lesion and determine the aetiology. For example, osteoarthritis of the neck is a common cause of this type of pain. For "tension headache" we need a new term. Any suggestions?

National Hospitals for Nervous Diseases

Queen Square,

London WC1N 3BG 